\title{
ELIMINATION OF SAFETY RISKS IN BIOGAS FACILITIES
}

\author{
Ján GADUŠ - Alena HAŠKOVÁ
}

\begin{abstract}
Currently in the frame of utilization of various forms of renewable energy sources an important support is given to spreading biogas facility operation. These facilities contribute significantly to the environment protection and partly to energy independence of the country. However their operation is connected with some safety risks which are often underestimated in practice. Biogas facilities belong to restricted facilities, what means that their operation must be in line with relevant requirements regarding to explosiveness of the environment, noise, vibrations etc. The contribution pays attention to various aspects of their safety operation.
\end{abstract}

Key words: biogas station, safety risks, operation safety, threat zones, occupational health and safety (OHS), meeting the safety rules, work safety management, Biomass Utilization Action Plan in Slovakia for the period $2008-2013$.

\section{ELIMINÁCIA BEZPEČNOSTNÝCH RIZÍK V BIOPLYNOVÝCH ZARIADENIACH}

Resumé: V rámci využívania rôznych foriem obnovitel’ných zdrojov energií je v súčasnosti výrazná podpora venovaná rozširovaniu prevádzkovania bioplynových zariadení. Tieto technológie prispievajú významnou mierou k ochrane životného prostredia a čiastočne aj k energetickej nezávislosti krajiny. Ich prevádzkovanie je však spojené s bezpečnostnými rizikami, ktoré sú v praxi často podceňované. Bioplynové zariadenia patria medzi vyhradené technické zariadenia, čo znamená že ich prevádzkovanie musí zodpovedat' príslušným požiadavkám či už vzhladom na výbušnost' prostredia, hluk, vibrácie a pod. Príspevok venuje pozornost' rôznym aspektom ich bezpečného prevádzkovania.

Kl'účové slová: bioplynová stanica, bezpečnostné riziká, bezpečnost' prevádzkovania, zóny ohrozenia, bezpečnost' a ochrana zdravia při práci (BOZP), dodržiavanie pravidiel bezpečnosti, manažment bezpečnosti práce, Akčný plán využívania biomasy v SR na roky 2008 - 2013.

\section{1 Úvod}

Podla proklamácií vlády SR (Programové vyhlásenie vlády SR, 2006) by sa na Slovensku mal do roku 2020 zvýšit' podiel obnovitel'ných zdrojov energie na celkovej spotrebe energie z pôvodných zhruba $4 \%$ na $20 \%$. V snahe zabezpečit' splnenie tohto záväzku Ministerstvo hospodárstva SR vytýčilo najambicióznejšie ciele v oblasti využívania biomasy, ktorá v súčasnosti predstavuje približne polovicu obnovitel'nej energie využívanej v EÚ (Stratégia vyššieho využitia obnovitel'ných zdrojov energie v SR, 2007).

$\mathrm{Na}$ Slovensku z hl'adiska energetického využitia najväčší potenciál má lesnícka a hlavne pol'nohospodárska biomasa, ktorá vzniká či už ako odpad alebo ako zámerný produkt.

Na výrobu bioplynu je možné využit' biomasu rastlinného pôvodu (zelené hmoty a siláže), živočíšneho pôvodu (exkrementy hospodárskych zvierat) a biomasu pochádzajúcu z potravinárskeho sektoru (odpad z potravinárskych prevádzok). Bioplyn sa produkuje na základe fermentačných procesov, pričom rozklad organických látok prebieha anaeróbnym spôsobom pomocou termofilných baktérií. Bioplyn produkovaný v bioplynových staniciach je následne možné využit' na výrobu elektriny a tepla.

Pri prezentácii problematiky využívania bioplynových staníc sa väčšinou zdôrazňujú pozitívne environmentálne aspekty ich prevádzkovania, t.j. ich priaznivý dopad na životné prostredie. V ovel'a menšej miere je pozornost' sústred'ovaná na problematiku dodržiavania pravidiel bezpečného prevádzkovania týchto zariadení.

\section{Technické riešenie bioplynových zariadení}

Z hl'adiska technického riešenia je možné zariadenia na získavanie bioplynu (bioplynové stanice) rozdelit' do troch základných skupín:

- jednoduché (primitívne, domové),

- pol'nohospodárske,

- priemyselné. 
V prípade všetkých troch skupín však k základným komponentom týchto zariadení (bioplynových staníc) patria nasledujúce jednotky (obr. 1):

- jednotka predprípravy a dávkovania biomasy,

- tepelne izolovaný anaeróbny bioreaktor (tzv. fermentor) s miešacou jednotkou,
- jednotka na úpravu a uskladnenie bioplynu, - jednotka na výrobu elektriny, resp. na kombinovanú výrobu elektriny a tepla (tzv. kogeneračná jednotka),

- konečný sklad vyfermentovaného substrátu (digestátu),

- kontrolná a regulačná jednotka (snímače, ovládacie prvky, monitorovací program).

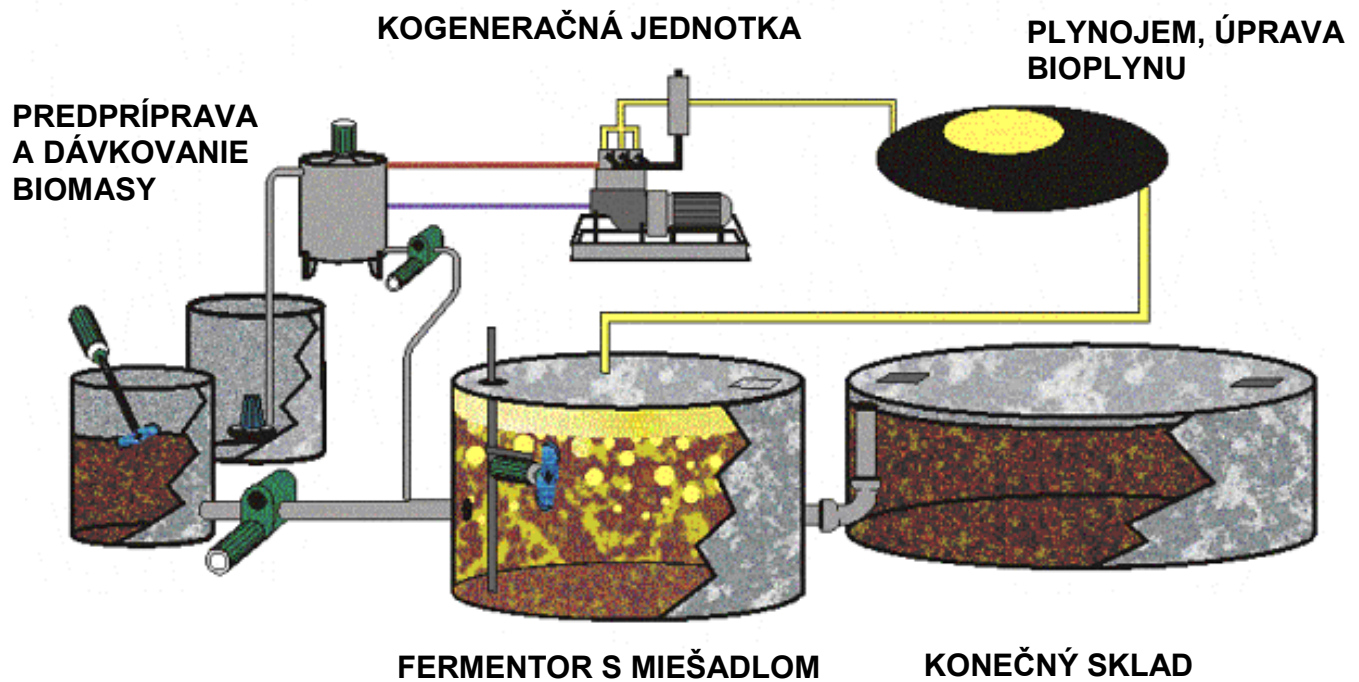

Obrázok 1: Hlavné časti bioplynového zariadenia

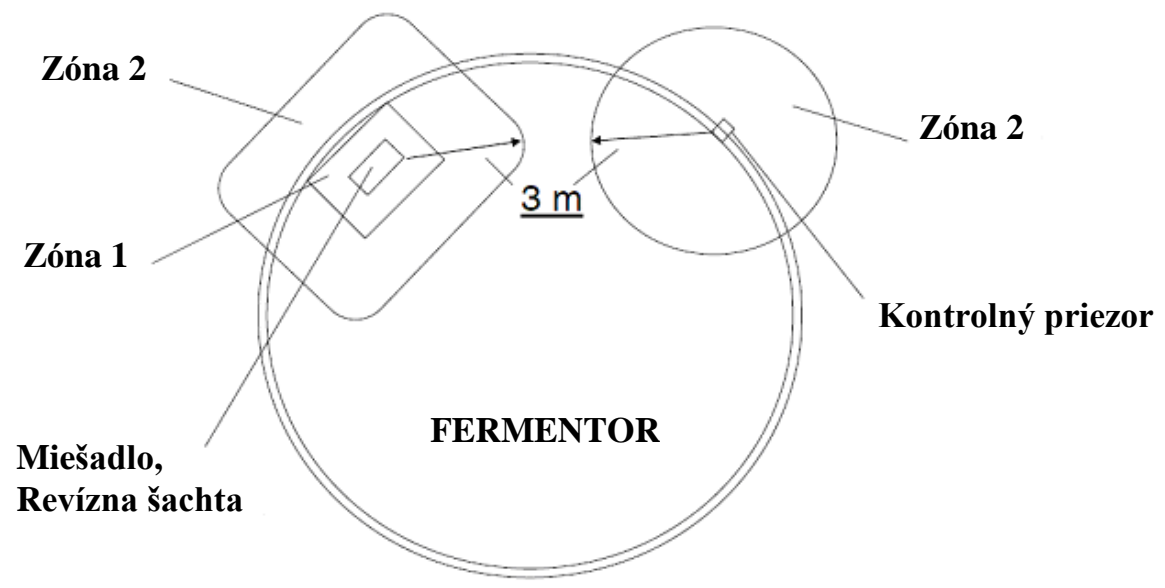

Obrázok 2: Bezpečnostné zóny na bioplynovom zariadení

\section{Riziká prevádzkovania bioplynových staníc}

Z technologického hl'adiska získavanie bioplynu a jeho následná premena na užitočnú energiu predstavujú technologicky menej náročné procesy. Avšak technologická jednoduchost' procesov prebiehajúcich $\mathrm{v}$ týchto zariadeniach je sprevádzaná vysokými bezpečnostnými rizikami, ktoré sú v praxi často podceňované, resp. dokonca prehliadané. Bezpečnostné riziká súvisia predovšetkým s prítomnost'ou a vysokou koncentráciou nebezpečných látok a s konštrukciou a charakterom jednotlivých komponentov bioplynových staníc, zostava ktorých vytvára pracovné prostredie, $\mathrm{v}$ ktorom sa 
pohybuje obslužný personál (obr. 2).

V priestoroch každej bioplynovej stanice sa trvalo (resp. dlhodobo) môže nachádzat' výbušná atmosféra. Bioplynové stanice preto musia byt' navrhované a konštruované tak, aby bola zabezpečená vel'mi vysoká miera bezpečnosti ich prevádzky ako celku. $Z$ tohto hl'adiska sa $\mathrm{v}$ rámci bioplynovej stanice sa rozlišujú priestory, v ktorých sa trvalo (resp. dlhodobo) nachádza výbušná atmosféra, priestory $\mathrm{v}$ ktorých $\mathrm{sa}$ výbušná atmosféra nachádza len krátkodobo a priestory, v ktorých sa výbušná atmosféra objavuje len sporadicky (resp. priestory bez výskytu výbušnej atmosféry). Príležitostná prítomnost' výbušnej atmosféry si vyžaduje zabezpečit' vysokú mieru bezpečnosti a sporadická, resp. krátkodobá prítomnost' výbušnej atmosféry si vyžaduje zabezpečit' bežnú úroveň bezpečnosti. $\mathrm{V}$ tomto zmysle sa $\mathrm{v}$ rámci bioplynových staníc deklarujú jednotlivé zóny ohrozenia výbuchom:

- zóna 0 - uzavreté priestory, kde sa nachádza výbušná atmosféra, zmes vzduchu, plynu, pary alebo hmloviny a to trvalo, dlhodobo alebo často (zóna 0 za normálnej prevádzky bioplynového zariadenia by sa nemala vyskytovat'),

- zóna 1 - priestory, v ktorých je treba počítat' $\mathrm{s}$ tým, že výbušná atmosféra sa $\mathrm{v}$ nich môže príležitostne vyskytnút',

- zóna 2 - priestory v ktorých sa nepočíta s výskytom výbušnej atmosféry.

Bezpečné fungovanie a prevádzkovanie bioplynových staníc musí byt' náležite zohl'adnené už v prípravnej fáze pri tvorbe ideového zámeru, zvažovaní možných koncepciî technického riešenia a hlavne pri príprave projektovej dokumentácie a realizácie výstavby. Koncepcia bioplynovej stanice musí obsahovat' jasný popis jej plánovaného technického riešenia, pri ktorom musia byt' rešpektované všetky aktuálne platné stavebné, bezpečnostné a environmentálne predpisy (normy, zákony, vyhlášky, smernice).

Okrem zámeru (kapacita a výkon zariadenia, druh využívanej biomasy, spôsob dovážania a spracovania biomasy) a koncepcie (technické riešenie) projektová dokumentácia musí sledovat' množstvo d'alších aspektov a kritérií, ktoré determinujú a určitým spôsobom (či už priamo alebo nepriamo) následne ovplyvňujú bezpečnost' práce a prevádzky bioplynovej stanice ako celku.
K takýmto aspektom patrí:

- náležitá pevnost' základov, dostatočná stabilita nadzemných konštrukčných častí,

- osadenie stavebných objektov (fermentor, plynojem, skladovacie nádrže), dodržanie predpísaných bezpečnostných vzdialeností medzi jednotlivými objektmi (napr. vzdialenosti medzi plynojemami a okolitými budovami, aj tými ktoré nie sú súčast’ou bioplynovej stanice, a dopravnými komunikáciami, vzdialenost' medzi plynojemom a blokovou tepelnou elektrárňou vnútri bioplynovej stanice),

- ochrana jednotlivých objektov pred zasiahnutím bleskom,

- kvalita, životnost' a bezpečnost' navrhovaných technológií,

- zamedzenie vzniku požiarov $\mathrm{v}$ dôsledku vnútorných ako aj vonkajších vplyvov (napr. v dôsledku elektrostatického náboja, zasiahnutia bleskom),

- chovanie konštrukčných materiálov a prvkov pri požiaroch,

- eliminovanie rizík explózií zmesí plyn /vzduch,

- dodržiavanie všeobecne uznávaných technických pravidiel pri projektovaní potrubí a armatúr,

- zamedzenie (neúmyselného) znepriechodnenia potrubí s následnými dôsledkami,

- náležitá kvalita exponovaných častí zariadení bioplynovej stanice (potrubia, fólie, miešadlá, senzory),

- zamedzenie únikom plynu (napr. z kondenzačnej šachty),

- ochrana všetkých častí plynovodu proti korózii a mechanickému poškodeniu,

- realizácia tepelnej izolácie nádrží z nehorl'avých materiálov,

- zabezpečenie elektrických zariadení osadených vo vnútri nádrží izoláciami chrániacimi ich pred výbuchom,

- zabezpečenie teplotnej stability a plynotesnosti plynojemov, ich odolnosti proti tlaku a UV žiareniu,

- zabezpečenie bezpečnosti vo výbušnom priestore plynojemu,

- zabezpečenie riešení dôsledkov výpadkov jednotlivých častí zariadenia bioplynovej stanice (čo sa stane v prípade poruchy),

- okamžitá zretel'ná signalizácia havarijných stavov a výpadkov jednotlivých zariadení,

- inštalácia analyzátorov bioplynu nepretržite monitorujúcich stav $\mathrm{CH}_{4}, \mathrm{CO}_{2}$ a $\mathrm{H}_{2} \mathrm{~S}$, 
- spôsob skladovania horl'avých a nebezpečných látok,

- energetická náročnost' jednotlivých prvkov (doprava, úprava biomasy, dávkovanie substrátu),

- potrebná kapacita a vel'kost' jednotlivých prvkov,

- bezproblémovost' spracovania rôzne kvalitnej navážanej biomasy.

\section{Manažment bezpečnosti práce}

Bezpečnost' fungovania bioplynových staníc nie je možné pustit' zo zretel'a ani po ich uvedení do prevádzky. Začatie prevádzkovania bioplynovej stanice znamená totiž ešte d’alšie rozšírenie spektra možných bezpečnostných rizík, na ktoré je treba dozerat' a ktoré je potrebné neustále zvažovat' a monitorovat'.

K základným rizikovým faktorom ovplyvňujúcim bezpečnost' práce prevádzkového personálu bioplynových staníc (negatívnym spôsobom) patrí:

- prítomnost' horl'avých a okysličujúcich látok (iniciácia požiaru, vznik výbušnej atmosféry),

- prítomnost' a používanie nebezpečných chemických látok,

- manipulácia s laboratórnym sklom,

- výskyt vysokých teplôt,

- nedostatočné zabezpečenie vetracích systémov,

- nedostatočná kontrola maximálnych prípustných koncentrácií látok so stanovenými maximálnymi prípustnými hodnotami,

- elektrické zariadenia bez krytí,

- nechránené pohybujúce sa časti strojov,

- výskyt klzkých podláh, poškodených podláh, podláh s nerovnost’ami,

- umiestňovanie káblov na podlahe,

- vykonávanie pracovných činností v priestoroch susediacich s prekážkami.

Ohrozenie zdravia a bezpečnosti práce obslužného personálu bioplynových staníc je však spojené s ovel'a širším spektrom rizík, často aj banálneho charakteru. Takými sú napr.:

- riziká úrazov $\mathrm{v}$ dôsledku nesprávneho používania elektrických zariadení,

- riziká úrazov spôsobených zásahom elektrického prúdu pri manipulácii s elektrickými zariadeniami vlhkými rukami alebo vo vlhkom oblečení,
- riziká pádov z výšky (z vyvýšených plôch a rebríkov) pri čistiacich a údržbárskych prácach a z vol'ných okrajov nezabezpečených ochranným zábradlím bez použitia prostriedkov osobného istenia, riziká pádov do odkrytých nádrží,

- riziká ohrozenia života v dôsledku nadýchania sa plynových splodín (zadusenie, otrávenie $-\mathrm{H}_{2} \mathrm{~S}, \mathrm{CH}_{4}, \mathrm{CO}_{2}$ ),

- riziká práce na odlúčenom pracovisku prítomnost' iba jedného zamestnanca.

Manažment bezpečnosti práce na bioplynových staniciach možno považovat' za integrálnu jednotu dvoch stránok. Jednou stránkou je nastavenie náležitých parametrov všetkých súčastí príslušnej bioplynovej stanice. Druhou stránkou je implementácia pravidiel bezpečnosti prevádzky a bezpečnosti a ochrany zdravia pracovníkov do každodenného života bioplynovej stanice. Implementácia pravidiel bezpečnosti prevádzky a bezpečnosti a ochrany zdravia pracovníkov do každodenného života bioplynovej stanice sa prejavuje napríklad:

- v zabezpečení obmedzenia prístupov do priestoru bioplynovej stanice, resp. do niektorých jej lokalít,

- v označení prístupov do priestorov so zvýšeným rizikom výbuchov a požiarov a ochranných zón,

- v označení únikových ciest,

- v dodržiavaní pravidiel protipožiarnej a protiexplóznej ochrany,

- v dodržiavaní obsluhy armatúr len z bezpečných stanovíšt',

- v zabezpečovaní zariadení dostupne umiestnenými bezpečnostnými poistkami a v zabezpečovaní ventilov k odberu plynu proti neúmyselnému otvoreniu,

- v zabezpečovaní a dodržiavaní ochrany pracovníkov pred hlukom (najmä v blízkosti kogeneračných jednotiek),

- v organizovaní pravidelných školení zamestnancov,

- vo vytváraní pravidiel práce a organizačných (prevádzkových) pokynov pre prácu v podmienkach so zvýšenými bezpečnostnými rizikami a pre prácu s nebezpečnými látkami,

- vo vytváraní systémov zadávania prác na jednotlivých zariadeniach spolu so systémami vykonávania dozoru nad výkonom týchto prác, 
- vo vytváraní pravidiel kontrolných

- vania, vo vytváraní systému vedenia

obchôdzok a systému kontroly ich dodržiaprevádzko-vých denníkov a ich kontroly.

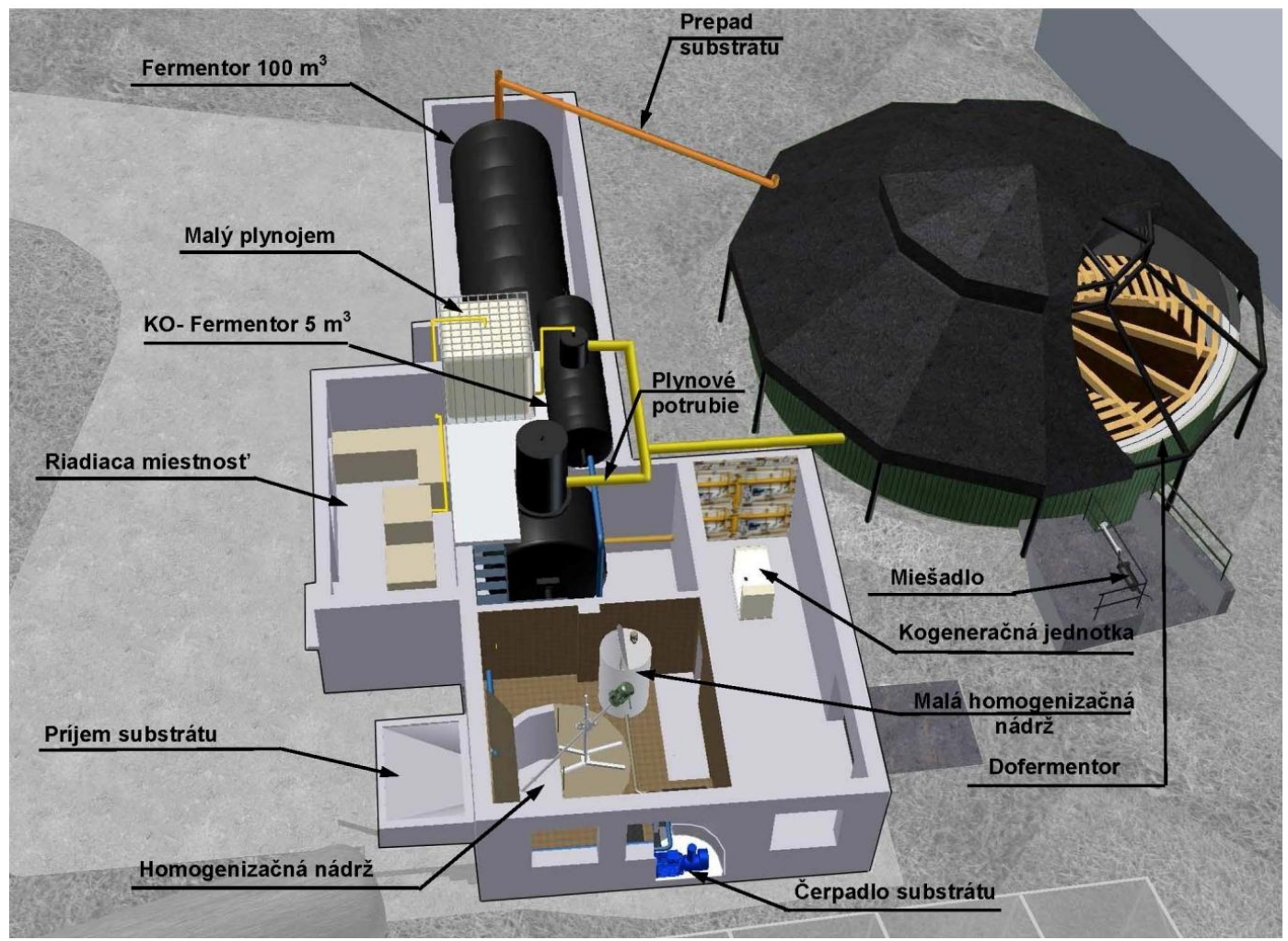

Obrázok 3: Usporiadanie jednotlivých funkčných celkov BPS v Kolíňanoch

\section{Záver}

V súčasnosti jedným z hlavných dokumentov pojednávajúcich o stratégii rozvoja a aktuálnych úlohách energetického priemyslu v zameraní na podporu rozvoja bioplynových zariadení na Slovensku je Akčný plán využivania biomasy na roky 2008 - 2013, ktorý prijala vláda SR na svojom zasadnutí vo februári 2008. I ked' Akčný plán sa bezprostredne bezpečnost'ou a ochranou zdravia pri práci nezaoberá, nepriamo sú aj $\mathrm{V}$ ňom reflektované požiadavky na bezpečnost' prevádzky bioplynových staníc. V Prílohe 2 tohto dokumentu sa nachádza napr. návrh podprogramu štátneho programu Výskum a vývoj technológii pestovania, spracovania a využivania biomasy na energetické účely, súčast'ou obsahu riešenia ktorého má byt' pre novo navrhované stroje a technologické linky vypracovanie súborov požiadaviek, a to v zameraní na:

- požiadavky technického charakteru,

- požiadavky technologického charakteru,

- požiadavky agrotechnického charakteru,

- požiadavky exploatačného charakteru,

- požiadavky environmentálneho charakteru.
Problematiku bezpečnosti a ochrany zdravia pri práci pri prevádzkovaní bioplynových staníc možno považovat' aj za súčast' informačnej kampane, na realizáciu ktorej sa upriamuje piaty ciel' kapitoly 4.5 Akčného programu (4.5 Ciel' 5 Informačná kampaň). Proklamovaná informačná kampaň má síce byt' zameraná predovšetkým na šírenie informácií o ekologických, ekonomických, sociálnych ale aj d’alších (pod čím môžeme rozumiet' aj bezpečnostných) aspektoch súvisiacich s rozvojom energetického využívania biomasy na Slovensku. Náplňou informačnej kampane má byt' šírenie všeobecných informácií, poskytovanie poradenskej a konzultačnej činnosti pre potenciálnych záujemcov, poskytovanie odbornej pomoci pri príprave projektov a zvyšovaní efektívnosti jestvujúcich projektov v oblasti produkcie biomasy a výroby energie ako aj poskytovanie odbornej pomoci pri samotnej realizácii projektov a pri prevádzke technológií v oblasti produkcie biomasy a výroby energie, do čoho môžeme opät' zahrnút' aj konzultovanie bezpečnosti prevádzky a zabezpečovanie ochrany zdravia obslužného personálu bioplynových 


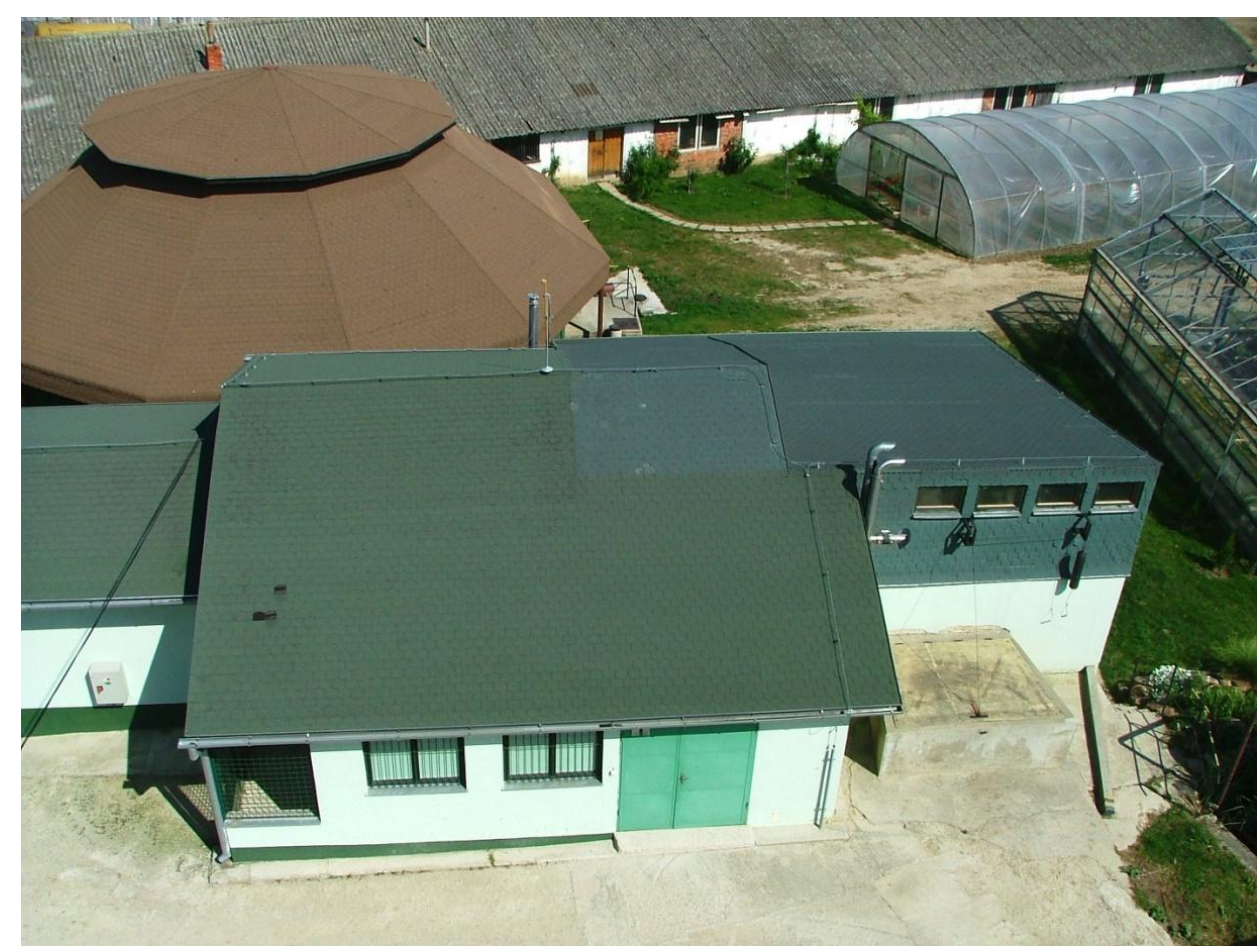

Obrázok 4: Pohl’ad na BPS v Kolíňanoch

staníc. Odborným garantom informačnej kampane je Ministerstvo pol'nohospodárstva SR so svojimi poradenskými centrami a s nimi spolupracujúcimi organizáciami. Jednou z takýchto spolupracujúcich organizácií je Centrum výskumu obnovitel'ných zdrojov energie Technickej fakulty SPU v Nitre, ktoré vo všeobecnosti na účely vyššie uvedeného typu využíva priestory a zariadenia svojej demonštračnej bioplynovej stanice $\mathrm{v}$ Kolín̆anoch (obr. 3, obr. 4).

\section{Literatúra}

[1] Akčný plán využívania biomasy na roky 2008 - 2013, 2008.

http://www.abe.sk/dokumenty/Akcny_plan.pdf [2] KOZÍK, T. - FESZTEROVÁ, M. Znaczenie calozyciowej edukacji w zakresie bezpieczenstwa i ochrony zdrowia przy pracy. In: Problemy profesjologii. ISSN 1895-197X, 2010, roč. 1, č. 1, s. 187-192

[3] MH SR: Stratégia vyššieho využitia obnovitel'ných zdrojov energie v SR, 2007. www.economy.gov.sk/strategia-vyssieho-vyuzitiaoze-6320/128005s

[4] Nariadenie vlády č. 393/2006 Z. z. o minimálnych požiadavkách na zaistenie bezpečnosti a ochrany zdravia pri práci vo výbušnom prostredí. www.uvzsr.sk/docs/leg/393_2006.pdf [5] Programové vyhlásenie vlády, 2006. http://www.zbierka.sk/mediagallery/zbierka_doc ument/file/example/file/2.pdf

[6] Vyhláška MPSVaR SR č. 508/2009 Z. z. o zaistení bezpečnosti a ochrany zdravia pri práci pre vyhradené technické zariadenia.

www.zbierka.sk/zz/predpisy/default.aspx?Predpis ID

Prof. Ing. Ján Gaduš, PhD.

Centrum výskumu obnovitel'ných zdrojov energie, Technická fakulta, SPU v Nitre

Tr. A. Hlinku 2, 94976 Nitra, SK

Tel: +421 376414108

E-mail: jan.gadus@uniag.sk

Www pracoviska: www.tf.uniag.sk/

departments/cvoze/dept_main.php

Prof. PaedDr. Alena Hašková, CSc.

Katedra techniky a informačných technológií

Pedagogická fakulta, UKF v Nitre

Tr. A. Hlinku 1, 94974 Nitra, SK

Tel.: +421 376408335

E-mail: ahaskova@ukf.sk

Www pracoviska: www.ktit.pf.ukf.sk 